\title{
ANAESTHETIC MANAGEMENT OF ANEPHRIC PATIENTS AND PATIENTS IN RENAL FAILURE
}

\author{
F. George Estafanous, M.D., "J. Kenneth Porter, M.D., " M.Y. El Tawil, M.D.," \\ and Kathryn L. Popowniak, M.D. $\nmid$
}

\section{INTRODUCTION}

IN THE LAST DECADE, great progress has been made in equipment design and techniques for haemodialysis. The survival of many patients in chronic renal failure or those who are anephric has been prolonged. In the last ten years, 4,164 patients with renal failure had a variety of surgical operations at the Cleveland Clinic (Table I). Different anaesthetic techniques were used. ${ }^{1}$ Operations were performed as treatment for pre-existing disease and as preparation for transplant. Parathyroidectomy and pericardiectomy were performed infrequently to treat the complications of renal failure.

\section{MAterial AND Study}

From September 1970 to December 1972, anaesthetics were administered to 1,124 patients who had renal failure or who were anephric. The management of anaesthesia was standardized and simplified with allowable modifications to suit each case. The first 300 cases were studied prospectively and the management was evaluated.

\section{Clinical Picture at Time of Operation}

The patients were usually underweight as compared to normal patients of the same age and height. Many were emotionally disturbed or depressed due to their disease and social and economic problems. The veins were small and each patient had an arteriovenous shunt or fistula in one arm. The diseases which initiated the renal failure (Table II) had effects other than renal on the overall condition of the patient (Table III).

Thirty-five per cent of the patients were hypertensive, with systolic arterial pressures of $160 \mathrm{~mm} \mathrm{Hg}$ or more, diastolic arterial pressures over $90 \mathrm{~mm} \mathrm{Hg}$, or both. The level of the arterial blood pressure was decreased immediately after dialysis. Electrocardiographic recordings revealed non-specific myocardial changes in 30 per cent of these patients and signs of left ventricular hypertrophy in 12 per cent. Arrhythmias were uncommon; premature ventricular contractions were recorded in only four patients; sinus tachycardia and bundle branch block were recorded in five others.

'Division of Anesthesiology, The Cleveland Clinic Foundation, Cleveland, Ohio. Ohio.

tDepartment of Hypertension and Nephrology, The Cleveland Clinic Foundation, Cleveland, 
TABLE I

Surgical Procedures on Patients with Chronic Renal Failure or Anephric Patients

\begin{tabular}{lcc}
\hline Procedure & $1 / 63-9 / 70$ & $9 / 70-12 / 72$ \\
Renal biopsy & 1618 & 522 \\
Arterio-venous shunt or fistula* & 94 & 115 \\
Renal transplant & 266 & 836 \\
Removal of transplant & 46 & 10 \\
Bilateral nephrectomy \& splenectomy & 902 & 272 \\
Parathyroidectomy & 82 & 107 \\
Pericardiectomy & 32 & 15 \\
Total & $\underline{3040}$ & 1124 \\
\hline
\end{tabular}

*Cases done under local anaesthesia are not included.

TABLE II

Diseases Predisposing to Renal Failute, Necessitating Renal Transplantation

\begin{tabular}{lr}
\hline \hline Chronic glomerulonephritis & 154 \\
Chronic pyelonephritis & 64 \\
Sclerosing glomerulonephritis & 51 \\
Polycystic disease & 22 \\
Systemic lupus erythematosus & 6 \\
Malignancy & 2 \\
Other causes & 47 \\
\hline
\end{tabular}

TABLE III

Complications of Diseases Causing Renal Failure and Their Effects on the Anaesthetic Management of the Patient

\begin{tabular}{ll}
\hline Problem & Result \\
\hline $\begin{array}{l}\text { Anaemia } \\
\text { Cypertension }\end{array}$ & $\begin{array}{l}\text { reduced oxygen carrying capacity of the blood } \\
\text { likelihood of cerebrovascular accident } \\
\text { pulmonary edema; postoperative cardiopulmonary } \\
\text { complications } \\
\text { Chronic infection and amyloidosis } \\
\text { from amylomidosis }\end{array}$ \\
$\begin{array}{l}\text { Liability to acute infection } \\
\text { Diseases accompanying congenital } \\
\text { kidney disease }\end{array}$ & $\begin{array}{l}\text { increased postoperative morbidity and mortality } \\
\text { Multiple drug therapy }\end{array}$ \\
$\begin{array}{l}\text { eg. congenital cystic pulmonary disease } \\
\text { suprarenal exhaustion; hypotension caused by } \\
\text { corticosteroid therapy; leukopenia caused by } \\
\text { immunosuppressive therapy; interactions between } \\
\text { digitalis and fluctuating serum potassium level; } \\
\text { possibility of hypotension in patients on } \\
\text { antihypertensive therapy }\end{array}$ \\
\hline
\end{tabular}

These patients were kept in satisfactory clinical condition by periodic haemodialysis, two or three times each week. The total number of dialyses these patients had before the operation varied between 10 and 340, with an average of 18. The amount of water removed by the last dialysis varied between $0.75 \mathrm{lb}$ and $7.0 \mathrm{lb}$, with an average of $2.7 \mathrm{lb}$. Every effort was made to dialyse the patient immediately before the operation, or the day before; in a few emergency situations the patient had his last dialysis 3 or 4 days before the operation. These patients consequently were overhydrated, but none had congestive heart failure. 
Due to the variation in time elapsed after dialysis, laboratory investigations were done routinely one hour before the operation. The findings follow.

The average blood urea nitrogen was $65 \mathrm{mg} / 100 \mathrm{mI}$ with a range between $19 \mathrm{mg} / 100 \mathrm{ml}$ and $152 \mathrm{mg} / 100 \mathrm{ml}$. Creatinine values varied between $2.8 \mathrm{mg} / 100$ $\mathrm{ml}$ and $24.9 \mathrm{mg} / 100 \mathrm{ml}$ with an average of $11.8 \mathrm{mg} / 100 \mathrm{ml}$. The average serum potassium level was $5.1 \mathrm{mEq} /$ liter. Elevated potassium values, up to $7.5 \mathrm{mEq} /$ liter were noticed when the operation was a few days after dialysis, and in one patient serum potassium was $2.8 \mathrm{mEq} /$ liter immediately after dialysis. The serum calcium level was low; a few patients had values of $6 \mathrm{mg} / 100 \mathrm{ml} \mathrm{to} 7 \mathrm{mg} / 100 \mathrm{ml}$, but there was no manifestation of tetany. At the time of surgery, $\mathrm{pH}$ varied between 7.45 and 7.39 .

Haemoglobin levels varied between $5.9 \mathrm{~g} / 100 \mathrm{ml}$ and $12.4 \mathrm{~g} / 100 \mathrm{ml}$ with an average of $8.1 \mathrm{~g} / 100 \mathrm{ml}$. The haematocrit varied between 15 per cent and 33 per cent with an average of 23.9 per cent.

Thirty per cent of the patients in our study were receiving antihypertensive drugs and 4 per cent of the patients were receiving digitalis therapy.

As these patients have high blood urea levels and almost always receive high doses of corticosteroids and immuno-suppressive drugs, they are more susceptible to infection and receive antibiotic therapy which may interact with the anaesthetic agents.

\section{Anaesthetic Management}

\section{Preparation}

None of the transplant operations were extreme emergencies, as cadaveric transplants could be perfused with the kidney perfusion machine* which allowed ample time for preparation of the patient. Antihypertensive medications were continued. Patients receiving corticosteroids were given $100 \mathrm{mg}$ or double the daily dose of hydrocortisone intramuscularly the night before the operation. The dose was repeated just before operation. An anaesthesiologist visited all patients the night before the operation. Attention was given to the possibility of drug interactions, and steps were taken to prevent them.

\section{Preliminary medication}

Atropine sulfate $0.5 \mathrm{mg}$, hydroxyzine hydrochloride (Vistaril) $0.5-0.7 \mathrm{mg} / \mathrm{kg}$ body weight, and hydrochlorides of opium alkaloids (Pantopon) $0.25 \mathrm{mg} / \mathrm{kg}$ body weight were given intramuscularly one hour before induction of anaesthesia. When Pantopon was contraindicated $0.75 \mathrm{mg} / \mathrm{kg}$ body weight of pentazocine lactate (Talwin) was substituted.

Transfusion and blood pressure cuffs were contraindicated in the arm which had the shunt; the arm was kept warm and protected during the operation, to prevent thrombosis. An intravenous infusion of 5 per cent dextrose in 0.2 per cent sodium chloride was begun using a Butterfly 21 -gauge needle and a microdrip set. If a blood transfusion was needed, it was administered through a 16-gauge or 18-gauge plastic canula (Angiocath ${ }^{\circledR}$ ).

*Belzer LT-400. 


\section{Induction of anaesthesia}

Oxygen in 100 per cent concentration was administered by face mask for 5 minutes. A dose of approximately $3.5 \mathrm{mg} / \mathrm{kg}$ body weight of thiopentone was then given to induce sleep. Just prior to tracheal intubation, the patient received succinylcholine chloride $1 \mathrm{mg} / \mathrm{kg}$ body weight. In any instance in which the serum potassium level was above $6 \mathrm{mEq} / \mathrm{L}$ and especially if the patient was receiving digitalis, d-tubocurarine chloride ( $4 \mathrm{mgm} / \mathrm{kg}$ body weight) replaced succinylcholine.

\section{Maintenance of anaesthesia}

Anaesthesia was maintained with 50 per cent nitrous oxide in oxygen, to which small concentrations ( 0.3 per cent- 0.5 per cent) of halothane were added. If the patient's liver function was impaired, or if he had received several halothane anaesthetics previously, intermittent intravenous doses of Pantopon $(3 \mathrm{mg}$ to $5 \mathrm{mg}$ each) were substituted. This was done in 14 cases in this series.

Muscle relaxation was achieved by the use of d-tubocurarine chloride 10-15 mgm initially, followed by incremental intravenous doses of $3 \mathrm{mg}$ to $6 \mathrm{mg}$ at a time. A total dose of $20 \mathrm{mg}$ to $40 \mathrm{mg}$ was adequate for operations lasting 2 to 4 hours.

Ventilation was controlled. A tidal volume of $10 \mathrm{ml}$ to $12 \mathrm{ml} / \mathrm{kg}$ body weight at a rate of 12 to 14 per minute was achieved with a mechanical ventilator. The pressures used and the inspiratory/expiratory ratio were adjusted to minimize the effects on blood pressure.

Supplementary doses of muscle relaxants were not given in the last half hour of the operation. In all patients, residual muscle relaxation was reversed with up to $1 \mathrm{mg}$ of atropine sulfate and 2.5 to $5 \mathrm{mg}$ neostigmine methylsulfate (Prostigmin Methylsulfate) (for adults) given intravenously. The patient was then allowed to breathe spontaneously. Extubation was accomplished at the end of the operation.

\section{Elevated serum potassium level}

When the serum potassium level was above $5.5 \mathrm{mEq} / \mathrm{liter}$, the patient was given a "cocktail" consisting of 5 per cent dextrose with 8.96 g sodium lactate, 10 units of regular insulin and $2 \mathrm{~g}$ calcium gluconate added for each $500 \mathrm{ml}$ of solution. This solution was given intravenously, initially at a rate of 60 drops per minute and adjusted after several determinations of the serum potassium level. The drip was continued until the next haemodialysis. The rationale for this mode of therapy is discussed below. If whole blood was needed, it was deionized first by a calcium cycle deionization set (Figure 1) to reduce its potassium content."

\section{Patients for parathyroidectomy}

All these patients received an infusion of 5 per cent dextrose in 0.2 per cent saline solution, to which was added $4 \mathrm{~g}$ calcium per $500 \mathrm{ml}$ of solution. This infusion was given slowly and continued for the first 24 hours postoperatively.

*JB-2 Ion Exchange Blood-Pack (Travenol). 


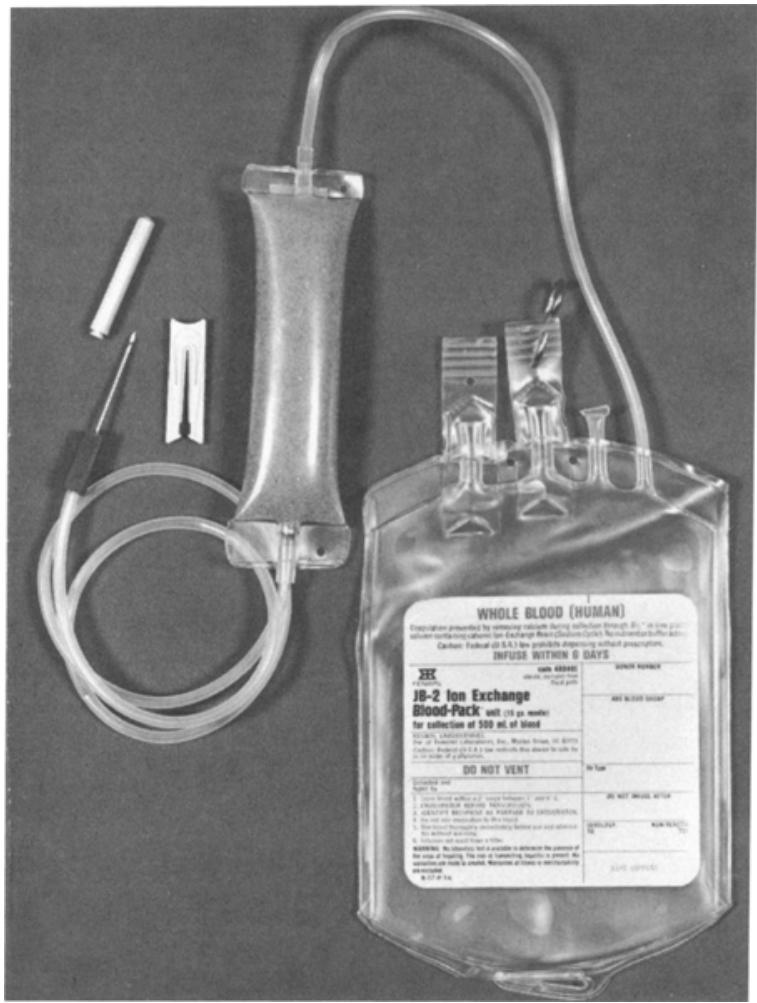

Figure 1. JB-2 Ion Exchange Blood-Pack for deionization of blood.

\section{Monitoring}

(A) At the time of induction of anaesthesia, data which must be available include: (1) results of last dialysis, and increase in weight after the last dialysis; (2) serum electrolyte levels, $\mathrm{pH}$, haemoglobin, haematocrit, blood urea nitrogen and creatinine levels.

(B) As the changes in the $\mathrm{pH}$ and serum potassium levels can adversely affect cardiac rhythm, the electrocardiogram was displayed continuously. Intraoperative determinations of serum potassium and $\mathrm{pH}$ were obtained in the event of arrhythmias or after massive transfusion or episodes of hypotension.

(C) The arterial blood pressure was measured every quarter hour or more frequently in instances of bleeding or hypotension.

(D) Urinary output was collected with an indwelling catheter and collection bag. The urine was analyzed and its volume measured.

These measures were continued into the postoperative period.

\section{Blood and fuid loss and replacement}

Blood and fluid loss were estimated by correlating visual losses, content of suction bottles, weighed sponges, pulse rate, and arterial pressure readings. Glucose 5 per cent in quarter-strength saline solution, and leukocyte-poor blood

-One unit of leukocyte-poor blood varied between 250 and $270 \mathrm{ml}$. 


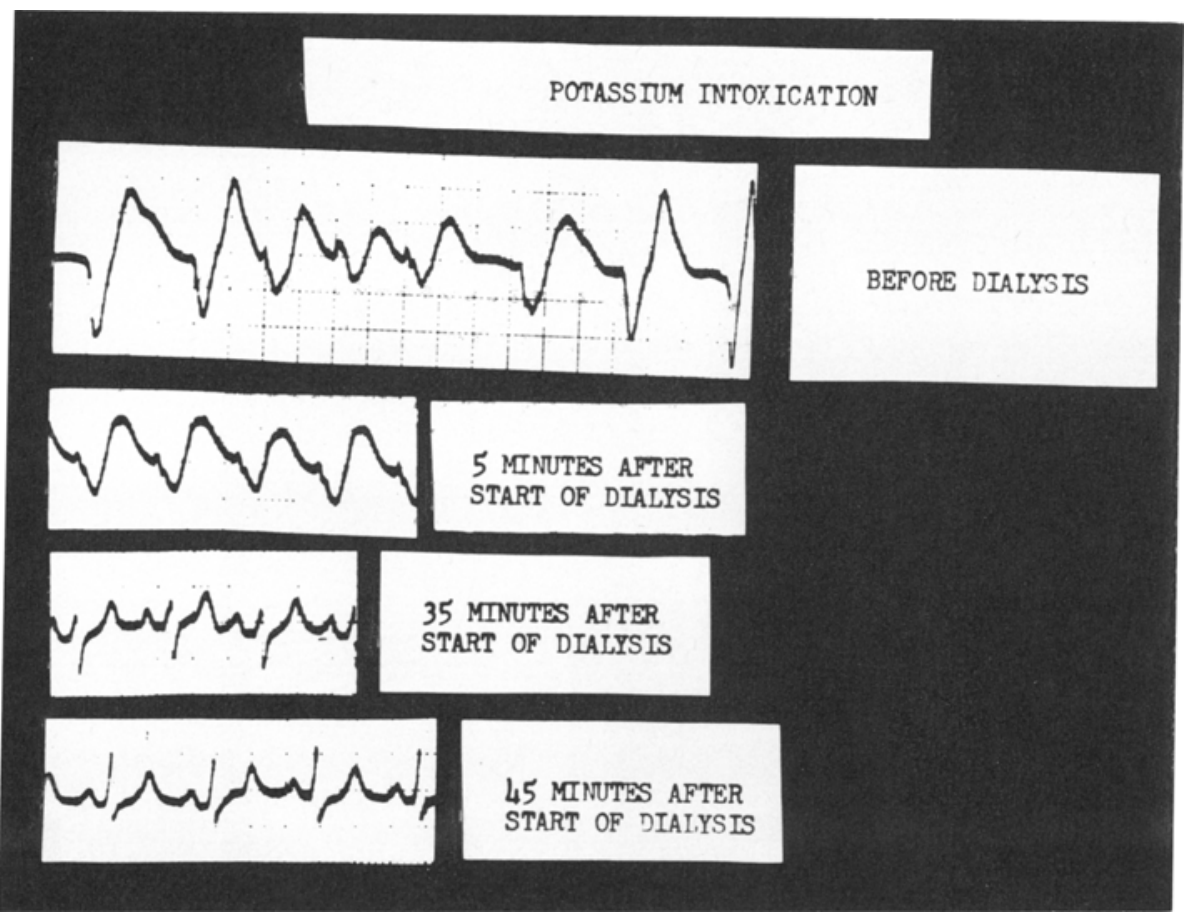

Figure 2. Electrocardiographic changes due to increased serum potassium levels and the effect of haemodialysis on these changes.

were used for replacement. The amount of blood transfused varied between 270 $\mathrm{ml}$ and $540 \mathrm{ml}$.

\section{Complications}

\section{Bleeding}

Unexpected bleeding from the site of vessels anastomosed for a transplant occurred in three patients. In one case bleeding was excessive and uncontrolled for some time and up to $2000 \mathrm{ml}$ of fluid and $2000 \mathrm{ml}$ of whole blood were transfused after deionization by the calcium cycle set. It was necessary to measure the central venous pressure in these patients to avoid over-transfusion.

\section{Hypotension}

No significant hypotension was recorded during induction of anaesthesia. A few episodes of hypotension occurred during operation, mainly due to pressure on the inferior vena cava by the abdominal retractor (Figure 2), from the packs, or both. Small, quick infusions of up to $200 \mathrm{ml}$ of fluid and tilting the head of the table down $15^{\circ}$ for a few minutes aided in correction of these episodes. The hypotension which accompanied massive bleeding was corrected immediately by fluid and blood replacement.

Hypotension occurred in the postoperative period in a few cases; it was mainly caused by restriction of the amount of fluid given. The arterial blood pressure returned to normal after administration of fluid. 


\section{Arrhythmias}

Premature ventricular contractions were observed in four patients during induction of anaesthesia. These persisted during maintenance, but caused no problems in the management.

\section{Delayed reversal of muscle relaxation and recurarization}

Respiratory depression manifested by inadequate tidal volume occurred in two patients. Stimulation of the ulnar nerve by a nerve stimulator did not show signs of residual curarization. The hypoventilation was attributed to central depression and was treated adequately by artificial ventilation for 2 to 3 hours postoperatively. There were no other signs of recurarization in any patient in this series. There was no mortality related to anaesthesia in any of the patients in this series.

\section{Postoperative Care}

Maintenance fluid therapy was 5 per cent dextrose in 0.45 per cent saline, given at a rate of $30 \mathrm{ml}$ per hour plus the previous hour's output. If diuresis was greater than $300 \mathrm{ml}$ per hour, two-thirds of the previous hour's output was given. Recipients of cadaveric or living donor allografts who were oliguric and required haemodialysis were given 5 per cent dextrose in 0.23 per cent saline at $30 \mathrm{ml}$ per hour plus the previous hour's output. Potassium was replaced as needed to maintain normal serum potassium levels.

\section{Immunosuppressive therapy}

Azathioprine (Imuran) $5 \mathrm{mg} / \mathrm{kg}$ body weight was given four hours to six hours preoperatively to patients with kidneys from living donors and generally during operation to patients receiving cadaveric renal allografts. Thereafter the dosage was maintained at $2 \mathrm{mg} / \mathrm{kg}$ body weight to $3 \mathrm{mg} / \mathrm{kg}$ body weight as long as the white blood cell count was more than 5,000 per $\mathrm{mm}^{3}$

Prednisone $2 \mathrm{mg} / \mathrm{kg}$ body weight was given to recipients of kidneys from living donors the day before and the morning of operation and for one week postoperatively. The dosage was decreased thereafter by $10 \mathrm{mg}$ every four to five days until a maintenance dose of $5 \mathrm{mg}$ to $10 \mathrm{mg}$ daily was established. Recipients of cadaveric allografts received prednisone $2 \mathrm{mg} / \mathrm{kg}$ body weight the day of operation. The dosage was adjusted as described for recipients of kidneys from living donors.

In addition to prednisone given orally, methyl prednisolone sodium succinate (Solu-Medrol) $250 \mathrm{mg}$ intravenously every six hours was begun the day before surgery for recipients of kidneys from living donors. It was begun the day of surgery for recipients of cadaveric kidneys and continued through the first postoperative day. Rejection was treated by intermittent doses of methyl prednisolone sodium succinate $20 \mathrm{mg} / \mathrm{kg}$ body weight.

\section{Discussion}

Recent advances in the techniques of haemodialysis and equipment prolonged the survival of patients with chronic renal failure. Haemodialysis corrected many of the pathological disorders and in turn created new problems for the anaesthesiologist (Table IV). 
TABLE IV

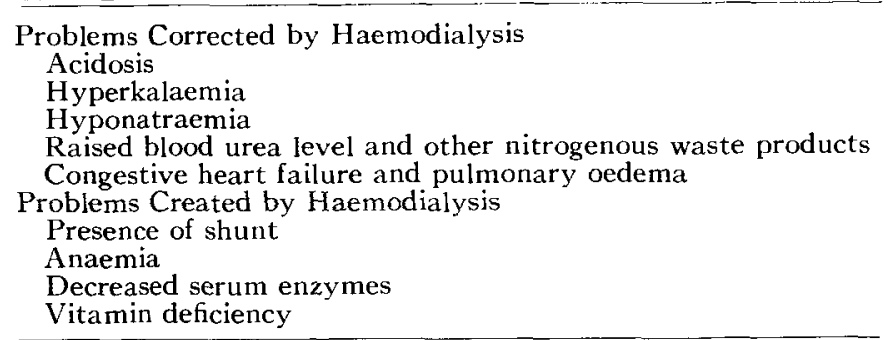

The patients were usually anaemic due to chronic infection, deficiency of erythropoietin and repeated haemodialysis.

Blood transfusions were kept at a minimum to avoid sensitization by blood donor leukocytes, which would increase the chance of rejection and serum hepatitis. Unless the patient became symptomatic from anaemia (dyspnoea on moderate exercise and tachycardia ) transfusions of leukocyte-poor blood were not given until the haematocrit dropped below 16 per cent. Usually the effect of transfusion lasted for only a few days. These patients were on corticosteroid and immunosuppressive drug therapy, and suffered from deficiency of plasma protein especially of gamma globulin. This rendered them more liable to infection and necessitated meticulous aseptic techniques and frequent antibiotic administration.

\section{Cardiovascular status}

Congestive heart failure is rarely a problem in a properly dialyzed patient. Hypertension leads to left ventricular hypertrophy, however, and this problem, together with atherosclerosis and severe anaemia, can predispose to anginal attacks.

\section{State of hydration}

Part of the water ingested and water produced by catabolic processes accumulates in the circulation until it is removed by dialysis. The longer the interval between dialysis, the more water accumulates. With these factors in mind, the amount of transfusion and infusion was adjusted to avoid pulmonary oedema and congestive heart failure. Over-restricting transfusion, however, may predispose to hypotension and inadequate perfusion of a transplanted organ. As the amount of post-transplant urine output varies between oliguria and polyuria, it must be considered in calculating the fluid replacement.

Maintenance of antihypertensive drug therapy avoids the undesirable effects of hypertensive episodes. In patients receiving continuous corticosteroid treatment, it is essential to give adequate corticosteroid cover because of the possibility of suprarenal depression. The possibility of interaction between antibiotics and muscle relaxants and the effect of serum potassium levels on patients receiving digitalis must be considered.

\section{Nitrogenous waste products}

The amount of nitrogenous waste products in the circulation affects the degree of orientation and the level of consciousness. High blood urea level is accompanied by decreased tolerance to barbiturates. Smaller doses are required in these patients. ${ }^{2}$ We substantiated this finding clinically, namely that smaller amounts 


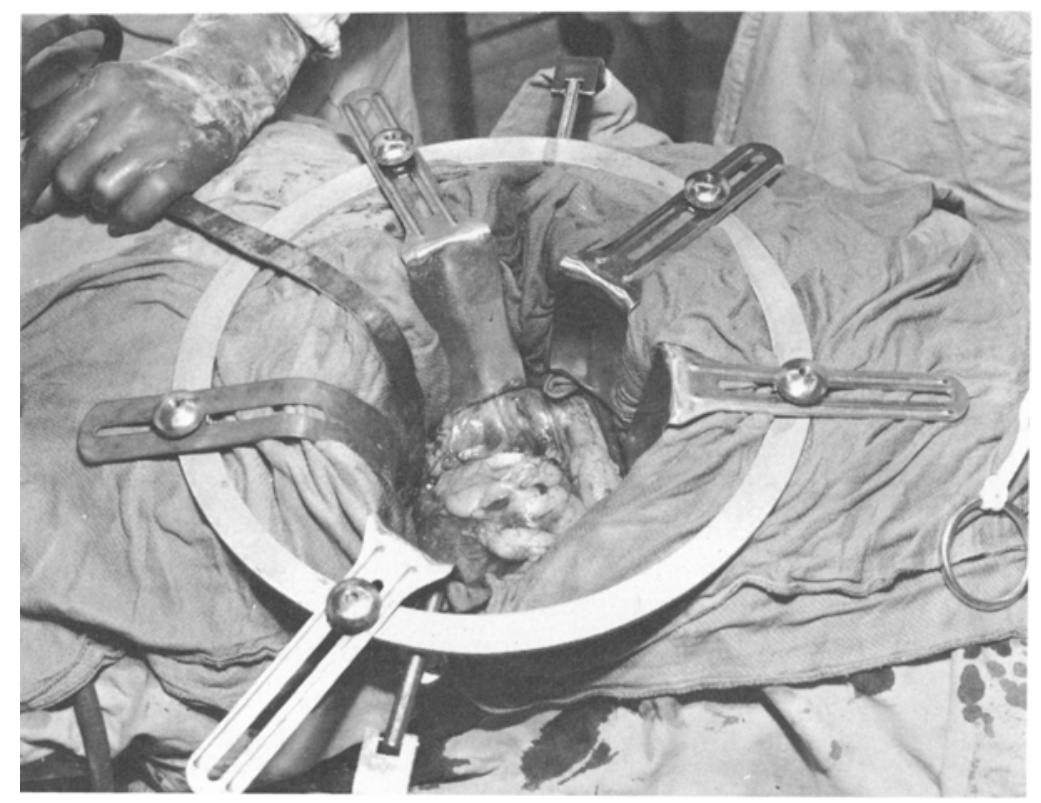

FIGURE 3. Abdominal retractor used for bilateral nephrectomy and renal transplantation.

of all general anaesthetic agents are required to maintain anaesthesia as compared to the patient with a normal BUN.

\section{Hydrogen ion concentration}

There was a tendency for acidosis to develop in these patients. Acidosis can be aggravated by an episode of hypotension, depression of respiration, or blood transfusion. Determination of $\mathrm{pH}$ is essential preoperatively and later as indicated.

\section{Serum potassium}

Potassium supplied in food and generated by catabolism can elevate the serum potassium level by $0.3-3 \mathrm{mEq} / \mathrm{L} /$ day in absence of kidney function. ${ }^{3}$ The increase in total body potassium is not as serious as the rise in serum potassium level, which is toxic to the myocardium. This toxicity is manifest by electrocardiographic changes in the following sequence as the serum potassium level rises: tall peaked T-wave, S-T segment depression, atrioventricular block and, finally, ventricular arrythmias which can lead to ventricular fibrillation or asystole. The cardiotoxic effects of potassium are increased by acidosis, hypocalcaemia and hyponatraemia. Haemodialysis eliminates the extra potassium from the body (Figure 3) and corrects acidosis and hyponatraemia. It is, therefore, the most effective treatment. In emergency situations when haemodialysis is not feasible, however, the cocktail we use is a very satisfactory substitute. The calcium counteracts the cardiotoxicity of potassium, and the glucose and insulin transfer the potassium from the serum to the intracellular compartment. This treatment is temporary. When it is discontinued the glycogen is mobilized and the potassium will be released into the serum again. Cation exchange resins are undesirable in treating hyperkalaemia in these patients because their use necessitates the administration of large amounts of fluid. 
Leukocyte-poor blood transfused to these patients (haematocrit value between 85 per cent and 90 per cent) contains little potassium. If cold or old whole blood is transfused during an emergency, however, it can elevate the serum potassium level dramatically. Deionization of whole blood eliminates this hazard, but the process of deionization requires 20 minutes per unit of blood and increases the amount of free haemoglobin. ${ }^{4}$

Immediately after haemodialysis, and if polyuria follows renal transplant, the serum potassium level may be reduced. This reduction can predispose to digitalis toxicity and ventricular arrhythmias.

\section{Parathyroid proliferation and serum calcium level}

The acidosis which accompanies chronic renal failure reduces the serum calcium level. In patients with prolonged failure the parathyroid gland proliferates, ${ }^{\mathbf{5}}$ decalcification of bone occurs. Extra care to avoid fractures is necessary in moving these patients. When parathyroidectomy is performed as a therapeutic measure, the serum calcium level may drop suddenly, predisposing to tetany.

\section{Uraemic pericarditis and cardiac tamponade}

Uraemic pericarditis has long been recognized as a complication of renal failure. With prolonged survival of these patients, cardiac tamponade is recognized more often. Repeated heparinization for haemodialysis can increase the problem by predisposing to haemopericardium. Partial pericardiectomy with creation of a pleuropericardial window is the proper management. ${ }^{6}$ This may be an emergency operation and the anaesthetist is faced with the problems resulting from cardiac tamponade and chronic renal failure in the same patient.

\section{Management of anaesthesia}

Time spent by the anaesthetist in measuring the preoperative parameters, discussed and ordering other necessary investigations is profitably invested. Planning of the anaesthetic management and monitoring techniques avoids many complications. Anaesthesia for renal transplant has been reviewed and discussed by many authors. ${ }^{7-9}$

Local, spinal, and epidural techniques are used frequently, ${ }^{10-11}$ thus avoiding the administration of many drugs which might accumulate in the absence of excretory functions. General anaesthesia often supplements the regional techniques, however.

With current knowledge of the behaviour of drugs in the absence of renal function, we prefer general anaesthesia for these ill, frequently neurotic patients.

In the absence of renal function, the channels for metabolism, distribution, and excretion of drugs are changed. ${ }^{12}$ The unexcreted metabolic products may have some of the actions of the original drug. The half-life of drugs administered will be prolonged. Considering these factors in association with the poor general condition of these patients, the doses of drugs must be reduced. Smaller doses are required to supplement the action of the original dose, and these are given at longer than normal intervals. ${ }^{13}$

Generally we found that 50 per cent to 75 per cent of doses and concentrations (related to body weight) used in normal subjects were effective in patients with chronic renal failure. 
Generous preliminary medication provides good sedation for the anxious patient. It facilitates the induction of anaesthesia. Smaller doses of sodium thiopentone are required, thus avoiding the possibility of hypotension. Preoxygenation increases the amount of oxygen dissolved in the plasma to act as a reserve for the anaemic patient during any episode of hypoxia during induction. Sodium thiopentone is metabolized mainly by the liver; its metabolites do not have anaesthetic effect.

Halothane in such small doses as we have used does not cause hypotension or renal cellular damage. ${ }^{14}$ It does not depress the renal function more than any other anaesthetic agent. ${ }^{15}$ In concentrations below 1.5 per cent, its effect on renal function (glomerular filteration rate, renal plasma flow, sodium and chloride excreation) are similar to preanaesthetic levels and the cardiac irregularities produced by such concentrations are negligible. ${ }^{16}$ Because of these properties and the rapid elimination of the drug, its effects on the diseased or transplanted kidney tend to be negligible. In the presence of poor liver function, history of hepatitis or a suspected sensitization, halothane is avoided and an intravenous narcotic analgesic should be used.

Methoxyflurane is mentioned only to caution that it should not be used because of its nephrotoxic properties. ${ }^{17}$ It should not be employed even in an anephric patient since there is no channel for excretion of the fluoride ion.

Of the narcotic analgesics used to supplement anaesthesia, Pantopon is preferred because of its potency and minimal circulatory effects. Pentazocine lactate is used postoperatively because it has the least effect on the circulatory system. Succinylcholine is used during induction of anaesthesia because it allows quick intubation and proper ventilation. It is avoided if the serum potassium level is over $5.5 \mathrm{mEq}$ /liter, especially if the patient is on digitalis therapy. Cardiac arrest and an increased incidence of arrhythmias are possible in such a case. ${ }^{18,19}$

For maintenance of muscle relaxation during the operation, a succinylcholine drip is not used because of the possibilities of decreased plasma cholinesterase levels, ${ }^{20}$ prolonged apnoea, and dual block. D-tubocurarine is the muscle relaxant of choice. In the absence of renal function its metabolism by the liver is enhanced. ${ }^{21}$ Small doses are sufficient to provide good muscle relaxation, a factor attributed to the behaviour of the drug and to the presence of a small degree of myopathy and neuropathy in patients with renal failure $(20 \mathrm{mg}$ to $40 \mathrm{mg}$ is sufficient for operations lasting two to four hours). The drug is given in small doses to avoid the possibility of hypotension. At the end of operation it is reversed adequately and no postoperative curarization was noted.

Gallamine was considered unsuitable for our patients. It is totally excreted by the kidneys in the dog. ${ }^{22}$ Signs of residual paralysis are reported after reversal of the neuromuscular block by neostigmine in patients with renal failure who received gallamine in normal doses. ${ }^{23,24}$

Pancuronium bromide (Pavulon) which has a hypertensive action ${ }^{25}$ may be advantageous for intubation when one is worried about the interaction with previous antihypertensive drug therapy and when succinylcholine is contraindicated. Little is known, however, about the excretory pathways for pancuronium in the absence of kidney function and its effects on a hypertensive patient. 
Maintenance of adequate blood pressure

Although these patients may be hypertensive and hypervolaemic, with continued antihypertensive treatment and the possibility of suprarenal exhaustion, hypotension is liable to occur. Adequate fluid replacement, avoidance of mechanical factors and proper doses of anaesthetic agents reduces the possibility of hypotension. If vasopressers are desperately indicated, however, sympathomimetics and methoxamine are better avoided, as they constrict renal vessels of even a transplanted kidney. Methylamphetamine, which increases the renal blood flow, is the preferred vasopressors in this situation.

\section{CONCLUSION}

Patients who are anephric or in renal failure present special problems. Repeated dialysis corrects only some of these problems. They must be understood and appreciated preoperatively any time one of these patients is a candidate for operation and anaesthesia. Careful preoperative assessment, haemodialysis, and preparation by the nephrologist are necessary to a successful course. The change in the channels of metabolism and excretion of anaesthetic agents in the presence of renal failure necessitates the use of modified doses and less frequent supplementation.

It has been our experience that the application of the simplified technique for anaesthetic management described herein, plus careful monitoring, has led to a bare minimum of intraoperative and postoperative complications. In the final analysis, a satisfactory outcome is based upon total care of the patient.

\section{RÉsUMÉ}

Les patients néphrectomisés ou en insuffisance rénale présentent des problèmes spéciaux. Chaque fois qu'une intervention chirurgicale et une anesthésie sont envisagées chez ces malades, ces problèmes doivent être analysés et compris en période pré-opératoire. L'évaluation pré-opératoire, l'hémodialyse et la préparation du patient par le néphrologue sont nécessaires pour une évolution favorable. Le métabolisme et l'excrétion des agents anesthésiques sont modifiés en présence d'insuffisance rénale d'oú la nécessité d'employer des doses plus faibles au départ et de diminuer la fréquence des doses d'entretien.

Selon notre propre expérience, l'application de techniques simples d'anesthésie associées à une surveillance étroite du malade ont réduit considérablement les complications per et post-opératoires.

Une prémédication adéquate fournit une bonne sédation au patient anxieux et facilite l'induction de l'anesthésie.

Une anesthésie générale avec protoxyde d'azote, oxygène et de faibles concentrations d'halothane ou associée à l'emploi des analgésiques narcotiques produit peu de changements. Le Pantopon s'est révélé un narcotique très efficace à cet égard.

Le méthoxyflurane est contre indiqué. La d-tubocurarine est le relaxant musculaire de choix et des petites doses fournissent un relâchement musculaire adéquat.

La succinylcholine en goutte à goutte n'est pas employée, vue la possibilité d'apnée prolongée entraînée par une diminution des niveaux de cholinestérase plasmatique ou l'apparition d'un bloc de phase II.

La gallamine n'est pas indiquée, car elle est excrétée entièrement par le rein. 


\section{ACKNOWLEDGMENT}

The authors would like to acknowledge the assistance of William H.L. Dornette, M.D., J.D., Director of Education and Research, Division of Anesthesiology, Cleveland Clinic Foundation, in the preparation of this manuscript.

\section{REFERENCES}

1. Номг, J., Sмгтн, E.R. Anesthetic management for renal transplantation. Proceedings of the World Federation of Anesthesia (1968).

2. LeE, J.A. \& AtKrnson, R.S. A synopsis of anesthesia, 6th ed. Baltimore, Williams and Wilkins, p. 507 ( 1968 ).

3. Jacobsen, E., Christransen, A.H., \& Lunding, N. The role of the anaesthetist in the management of acute renal failure. Brit. J. Anaesth. 40:442 (1968).

4. Estafanous, F.G. Anesthesia for patients in renal failure. Presented at the 12th Meeting of the Austrian, German, and Swiss Societies of Anaesthesiology, Bern, 1971.

5. Berson, S.A. \& YALOw, R.S. Parathyroid hormone in plasma in adenomatous hyperparathyroidism, uremia and bronchogenic carcinoma. Science 154: 907-910 (1966).

6. Beaudry, C., Nakamoto, S., \& KolfF, W.J. Uremic pericarditis and cardiac tamponade in chronic renal failure. Ann. Int. Med. 64: 990-995 (1966).

7. Katz, J., Kounts, S.L., \& Corn, R. Anesthetic considerations for renal transplant. Anesth. \& Analg. 46: 609-613 (1967).

8. Samuel, J.R. \& Powelr, D. Renal transplantation. Anaesth. 25: 165-176 (1970).

9. Strunin, L. Some aspects of anaesthesia for renal homotransplantation. Brit. J. Anaesth. 38: 812-822 (1966).

10. Vandam, L.D., et al. Anesthetic aspects of renal homotransplantation in man, with notes on the anesthetic care of the uremic patient. Anesthesiology 23: 783-792 (1962).

11. WYant, G.M. The anaesthetist looks at tissue transplantation: three years' experience with kidney transplants. Canad. Anaesth. Soc. J. 14: 255-275 (1967).

12. Reidenberg, M.M. Renal function and drug action. Philadelphia, Saunders (1971).

13. BennetT, W.M., Singer, I., Coggins, C.H. A practical guide to drug usage in adult patients with impaired renal function. J.A.M.A. 214: 1468-1475 (1970).

14. Corrsen, G. Effects of halogenated anesthetic agents on human embryonic kidney cells. Anesth. \& Analg. 48: 858-865 (1969).

15. Hudon, F., et al. Clinical observations on fluothane anaesthesia. Canad. Anaesth. Soc. J. 4: 221-234 (1957).

16. BLackmore, W.P., et al. Renal and cardiovascular effects of halothane. Anesthesiology $21: 489-495$ (1960).

17. Crandell, W.B., Pappas, S.G., \& MacDonald, A. Nephrotoxicity associated with methoxyflurane anesthesia. Anesthesiology 27: 591-607 (1966).

18. Roth, F. \& Wuthrich, H. The clinical importance of hyperkalaemia following suxamethoxium administration. Brit. J. Anaesth. 41: 311-316 (1969).

19. DowDy, E.G. \& FABIAN, L.W. Ventricular arrhythmias induced by succinylcholine in digitalized patients: a preliminary report. Anesth. \& Analg. 42: 501-513 (1963).

20. Holmes, J.H., Nakamoto, S., \& Sawyer, K.C. Jr. Changes in blood composition before and after dialysis with the kolff twin coil kidney. Trans. Amer. Soc. Art. Int. Organs 4: 16 (1958).

21. Cole, E.N., Brewer, H.W., \& Smitr, D. The metabolism and elimination of d-tubocurarine-H ${ }^{3}$. Anesthesiology 28: 309-317 (1967).

22. Feldman, S.A., Cohen, E.N., \& Colling, R.C. The excreation of gallamine in the dog. Anaesthesiology 30: 593-598 (1969).

23. Churchill-Davioson, H.C., Way, W.L., \& de Jong, R.H. The muscle relaxants and renal excretion. Anesthesiology 28: 540-546 (1967).

24. Fainley, H.B. Prolonged intercostal paralysis due to a relaxant. Brit. Med. J. 2: 986 (1950).

25. LoH, L. The cardio-vascular effects of Pancronium bromide. Anaesthesia 25: 356-363 $(1970)$. 